\title{
Tax Crime Investigation
}

\author{
Amarilda Xhaferri \\ European University of Tirana, Tirana, Albania \\ Email: idaxhaferri@yahoo.com
}

Received 10 May 2014; revised 25 June 2014; accepted 6 July 2014

Copyright (C) 2014 by author and Scientific Research Publishing Inc.

This work is licensed under the Creative Commons Attribution International License (CC BY).

http://creativecommons.org/licenses/by/4.0/

(c) (i) Open Access

\begin{abstract}
This paper outlines key activity principles of tax crime investigation, describes the present skills as well as qualification requirements which are likely to be imposed in the future. The final part of the paper provides some proposals for the ways to implement the requirements by defining skills improvement opportunities for investigators and investigators of operational cases. It also describes methods of office employees' skills improvement, crime prevention and IT sphere.
\end{abstract}

\section{Keywords}

Tax, Crime, Investigation, Skills

\section{Introduction}

Tax crime investigation [1] units have been established upon discovering poor investigation of crimes recorded by tax authorities. The underlying reason was the fact that apart from crime investigation qualifications [2], the persons responsible for investigation of tax crimes had to have excellent knowledge of tax legislation. Tax legislation expertise requirements applicable to employees of criminal departments who will be responsible for crime investigations shall be formulated by taking into account criminal activities which are the object of their investigation... In order to disclose and investigate professionally pre-planned illegal operations, investigators should also possess specific expertise. In many cases, such crimes should be investigated by highly-skilled tax crime investigators... This implies that investigators of tax criminal departments are subject to high requirements. It is a necessity, considering the circumstance that many tax crime investigations are very complex and infrequently of a large volume. Upon setting up separate programs at Police higher school [3], and introducing practical training upon their completion, main skills requirements have been formulated at tax crime investigation units. Besides, during the recent decade of existence of tax crime investigation units the Tax Department has acquired a lot of valuable experience and expertise about investigators' skills whose improvement is particularly important.

\section{Qualifications of Tax Crime Investigators}

In prosecutors' opinion, a fully-reliable assessment of tax crime investigators' skills could not be performed on 
the basis of material available. At present most investigators are highly-skilled; many of them have been previously employed as experts or tax auditors at the Tax Department and therefore have a lot of experience of dealing with reports. Great basic crime investigation skills are acquired at the police higher school which offers separate training programs and practical training upon their completion.

The skills necessary for crime investigation have been improved by acquiring more experience and adopting other measures, such as expanded training in the methods of interrogation, and application of alternative systems, Sweden and France are the first models in which other countries are referred. Besides, many investigators perform book-keeping evaluations in cases of book-keeping crimes. The work of operational activities is also rapidly improving. Creation of the register of operational activities as well as introduction of I-base and Analyst's Notebook software has made activity development a lot faster. The instruments of work are a natural part of activities of tax crime investigators. Some investigators were specialized in this particular sphere; some new employees possessing special skills have been hired. Some office employees all over the world as in Spain for example, have completed administrative training and regularly attend meetings where they share their experience; that's how skills are improved and new skills improvement instruments are created.

\section{Qualification Requirements}

All tax crime investigators should be well familiar with tax legislation. The majority of persons hired to work at tax crime investigation sector have worked at the Tax Department and therefore possess sufficient skills in the sphere of taxes. In Albania this is a routine of working. The majority has worked as tax auditors and therefore has substantial experience of dealing with reports. Still, some employees hired from within the system require additional training, while employees hired from the outside require continuous comprehensive long-term training and additional practical training at one or several fiscal sectors of the Tax Department. Maintaining the acquired skills is very important. Numerous changes take place in the tax system; all tax crime investigators should be offered an opportunity to participate in all general introductory and thematic training courses arranged for other employees of the Tax Department. Also, tax crime investigation departments are always included as a target group in the Tax Department when sending invitations to attend training course [4] or launching specific projects where criminal tax activities are likely to occur. Experience of dealing with reports is also highly important, particularly in major cases which involve investigation of several enterprises, book-keeping or debtors' crimes. The expertise should be kept up-to-date and improved continuously. Some tax crime investigation sectors might require special expertise, such as experience of dealing with reports or knowledge of certain taxes. Provision for improvement of the expertise should be made in individual skills improvement plans.

\section{Crime Investigation}

According to the original proposal approved by the government, the long-term objective of tax crime investigation units is investigation of all tax crimes registered at the Tax Department. The work towards achieving the objective is in progress; tax crime investigators are given more responsibility in investigating complex and large-volume cases. In further pursuit of the set goal, it is very important that prosecutors regard tax crime investigators as being properly qualified to investigate tax crimes, etc.

If prosecutors believe that qualification of investigators employed at tax crime investigation units is high and continuously improved, tax crime investigators are likely to continue getting more responsibilities to investigate tax crimes. Interrogation is an important element of pre-trial investigation; therefore this field should receive even more attention. The report proposes to arrange new trainings designed to improve expertise in this sphere.

The higher general qualification requirements in tax crime investigation units also boost the need for deeper and specialized expertise. Personal skills improvement plan of each investigator should provide for proper methods to pursue the objective. Operational work of tax crime investigation units has significantly expanded over the recent years. More and more investigators engage in operational work full-time; this sphere of work is expected to expand even further. The requirements applicable to investigators will get higher as the volume of operational work at tax crime investigation units increases. Partial shift of the nature of operational activities is in progress: introduction of the Register of National Operational activities of the Tax Department (RNOATD) is being started; therefore the need for IT and analytical expertise increases significantly. This category of employees can also specialize in certain areas which have to be set forth in personal skills [5] improvement plans. It is important that employees of this category are offered the same introductory trainings as those offered to other 
subunits of the Tax Department as well as skills improvement required to perform specific assignments of tax crime investigation units. Office employees might also encounter specific work assignments and requirements, therefore, specialized skills improvement might become a necessity and should be provided for in personal skills improvement plans. Qualification of this employee category is important for the overall efficiency of tax crime investigation Directory and their co-operation with other institutions.

\section{Skills Improvement. Basic Qualification Expertise}

The base of activities of tax crime investigation consists of high qualifications of investigators in the sphere of taxes and their knowledge of procedures, etc. effective at the Tax Department. The majority of new employees are former members of staff of other subunits of the Tax Department therefore such qualification requirements are quite common when hiring new employees. Tax crime investigator should comply with basic requirements in the following fields:

- VAT;

- AG/F taxes;

- Natural persons' taxation;

- Legal entities' taxation;

- Trade companies with stakeholders; private limited liability companies;

- Confidentiality;

- Procedures;

- Audit/Tax Control;

- Taxation Database/Tax Systems.

The training is followed by practical training. At present the practical training in different regions of the country differs both in terms of duration, and place [6]. Practical training should be conducted at police/Economic Crime Investigation Service. The Tax Department continuously offers its employees training courses [7] of various forms: introductory and thematic training, etc. It is important that employees of tax crime investigation units are not forgotten. At this stage division of investigators takes place: the majority concentrates on expertise in the sphere of crime investigation, while others choose operational activities. Annexes 2 and 3 provide a graphic depiction of crime investigators' and operational cases investigators' qualification expertise improvement as it should be. IT skills requirements are increasing in all tax crime investigations. This sphere calls for particular attention. The demand for such skills should be particularly high among investigators of operational cases because efficient operational work requires processing and analysis of large volume of material kept in specialized databases of operational activities. Investigation Directory should possess their own IT specialists who could offer assistance in data review and analysis. Special training should be arranged for such experts. The most important spheres of crime investigators [8] skills improvement are interrogation methods and IT, as well as upgrading of expertise in certain issues related to tax administration and legal matters.

It has been established that there is a need for skills improvement of investigators specialized in operational cases. This specialization can be acquired at any time, but as a rule, before acquiring the specialization, investigators should have at least two years of tax crime investigation experience. Database management software and questionnaires used in operational activities, unusually in conjunction with Analyst's Notebook.

Analyst's Notebook, the basics. For first this method of working was used in Sweden Compiling various diagrams and graphic presentations by bringing together units/objects selected from a large information flow; adapting the software to one's own needs. Creation of structured text files in Excel and Word and importing them into Analyst's Notebook. Functions of the analytical program, e.g. search methods or models, are analyzed. Work methodology for doing operational activities analysis.

\section{Specialized Training Crime Investigators}

Specialized training might become necessary after 4 - 5 years of crime investigation work (in certain cases the timing may be different). Such training should be more tailor-made, it provides an opportunity to specialize in the employee's particular spheres of activities. It can be training about various kinds of taxes, types of crime, investigation methods, etc. The examples of the training presented below are considered as being relevant to most investigators. The nature of skills improvement depends from the type of activities carried out and individual needs of each investigator for example illegal employment investigation [9]. 
It is also important not to forget the category of more experienced investigators and invite them to attend introductory and thematic training courses. This was the reason for creating this specialization stage in the scale of skills improvement.

TCIU III [10], the proposed content of the course covers interrogation situations. It is proposed to develop a five-day course; the first two days would be used to discuss personality types, additional information about other cultures would be provided. The remaining three days would be dedicated to explaining interrogator's role and the interrogation situation itself: personality test would be performed in the beginning of the first day in order to get to know oneself better and get a better knowledge about one's own and other people's behavior. This would be followed by two practical days of discussing the interrogation situation; attendees would be asked to take an active part and share their experience.

Interrogation Methodologies; Specialized [11]. It is a three-day course. The Group suggests that the course should discuss different interrogation methodologies and their links with a criminal act description. It should be a practical course, a major part of the course should be dedicated to the discussion of practical cases; duration3 days.

Result Presentation Models [12]. It is important to be able to explain results, etc. of complex investigations in a pedagogical fashion; a part of training time should therefore be dedicated for this purpose.

Analyst's Notebook, Level 2-extension of the basic course which provides more thorough knowledge of functions of the analytical software and import methods.

Surveillance during Tax Crime Investigation. Mandatory training for investigators who intend to specialize in the sphere of external surveillance

Experience Transfer within tax crime investigation units. A fixed form of sharing experience with experienced investigators is a good and desirable skills improvement method which has been included into the training and become a natural part thereof. Representatives of other law and order institutions, e.g. prosecutors, police officers or economists have been invited. When cases occurring in a particular region [13] are used as a basis, such experience transfer exercises might be arranged and conducted in the regions of the respective tax crimes investigators. Such experience transfer courses should offer an opportunity to extend work organization at tax crimes investigation units and improve it, if necessary.

\section{Conclusions}

Practical training at fiscal subunits of the Tax Department has been one of the elements of skills maintenance in the sphere of tax legislation and Tax Department apparatus. The spheres of taxation, VAT and taxes payable by the employer offer the greatest amount of experience to tax crime investigators. In order to make sure that the practical training is truly effective, it should last at least $3-4$ months [14]. The practical training has been planned according to the existing work assignments; a variety of aspects should be taken into account; practical training has been conducted under guidance.

In the process of their skills improvement, tax crime investigators would benefit a lot from practical training at other law and order institutions, such as Fraud Department of the Police or Criminal Services of the Customs Office. Such practical training should also last for approx. 3 - 4 months; it should be pre-planned and be conducted under guidance.

Result Presentation Models. It is important to be able to explain results, etc. of complex investigations in a pedagogical fashion; a part of training time should therefore be dedicated for this purpose.

Experience Transfer within tax crime investigation units. A fixed form of sharing experience with experienced investigators is a good and desirable skills improvement method which should be included into the training and become a natural part thereof. Representatives of other law and order institutions, e.g. prosecutors, police officers or economists might be invited. Experience transfer should continue for 2 - 3 days, in groups which should not be too numerous; preferably, a particular subject should be chosen each time.

ADP Training (ADP-Automated Data Processing). In order to perform operational work effectively, excellent knowledge of ADP is required, therefore a variety of specialized training courses have been offered in many subjects. Although employees rapidly improve their skills, the biggest amount of expertise is accumulated at the police; therefore, it might be beneficial for investigators of operational cases to undergo practical training at an operational activities subunit of the police or the customs office.

In addition to the courses listed above, a number of other training courses designed to help extend the available expertise might also be developed for skills improvement purposes; such courses might be specifically tai- 
lored for investigators of operational cases; they might also be arranged at other enterprises. Interactive training in the use of the Internet, practical training, etc. might also be necessary. Special foreign language courses, additional IT courses, etc. might be examples of the spheres which need improvement. Qualification basis of employees in this category consists of the same skills as those possessed by employees of the Tax Department, e.g. confidentiality, document registration, etc. The necessity to improve their skills is determined by the special kind of activities of tax crime investigation units, e.g. case handling, sending documents to prosecutors/receipt of documents from prosecutors, special case handling systems, practical handling of seizures, etc. Considering the fact that these employees account for a small part of the nationwide total number, basic skills should be acquired by methods other than attending traditional courses, e.g. by transferring the employee to another position in the same workplace, or, where possible — offering to do practical training at another tax crime investigation unit.

\section{Acknowledgements}

This work was supported by my father, Viron Xhaferri, and I want to thank him for all what he did and continue doing for me. Thank you dad!

Any opinions, findings, and conclusions or recommendations expressed in this material are those of the author and do not necessarily reflect the views of the others.

\section{References}

[1] Criminal Law.

[2] (2008) Penal Law of Albania.

[3] Fletcher, M., Loof, R. and Gilmore, B. (2008) EU Criminal Law and Justice. Edward Elgar Publishing Ltd, London. http://dx.doi.org/10.4337/9781848443884

[4] Tax Department's Manual of Investigation.

[5] Elezi, I. (2009) Penal Law. Erik Editions, Tirane.

[6] Voluntary Corrections and Additional Taxes.

[7] VAT Fraud, Albanian Tax Issues.

[8] Illegal Employment-Complex Cases. Methodologies. www.ebraria.com

[9] Information about Financial Police. State Criminal Police Bureau.

[10] Interpol, Europol, Provisions of the Schengen Treaty and the Project of Police and Customs Office Representatives in the Nordic Countries.

[11] Bankruptcy and Insolvency Rules Creditors at the Tax Department International Issues, Information about Criminal Cases and International.

[12] Magazine of the Intra European Organization of Tax Administration (2007) Tax Tribune Magazine. http://www.iota-tax.org/publications/tax-tribune.html. IOTA 2007

[13] Ministry of Finance (2008) On Tax Procedures in the Republic of Albania. Law No. 9920.

[14] (2002) Laws on Business. Tirana. http://www.absa.gov.al/v2/dokumenta/baza_ligjore/ligji_9901.pdf 
Scientific Research Publishing (SCIRP) is one of the largest Open Access journal publishers. It is currently publishing more than 200 open access, online, peer-reviewed journals covering a wide range of academic disciplines. SCIRP serves the worldwide academic communities and contributes to the progress and application of science with its publication.

Other selected journals from SCIRP are listed as below. Submit your manuscript to us via either submit@scirp.org or Online Submission Portal.
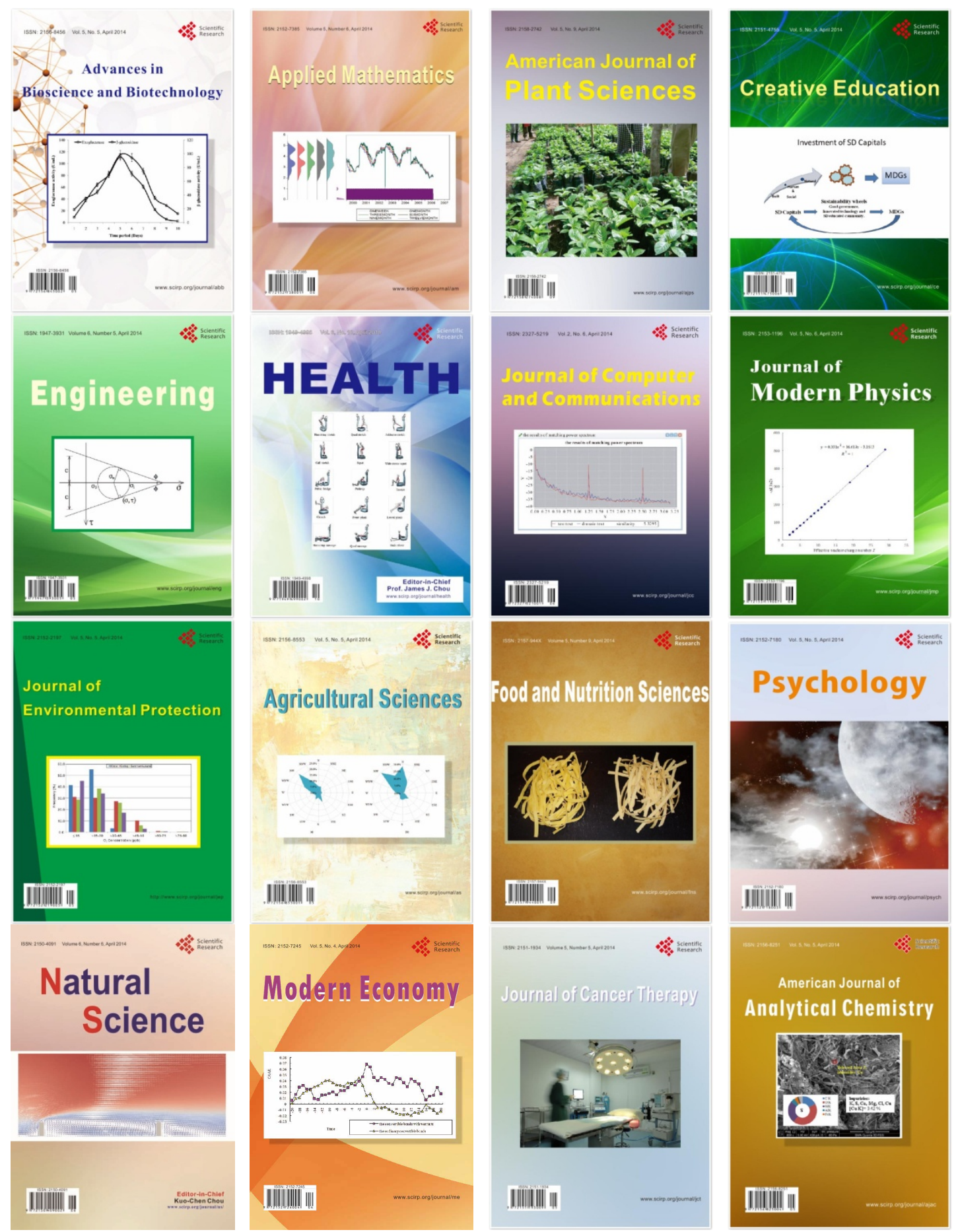